\title{
PELATIHAN MENGHITUNG HARGA POKOK DAN PEMBUKUANNYA BAGI PENGUSAHA DODOL DI DESA BOJONGGEDE KABUPATEN BOGOR
}

\author{
Renny Husniati ${ }^{1}$, Yoyoh Guritno ${ }^{2}$, Dewi Cahyani Pangestuti ${ }^{3}$ \\ ${ }^{1}$ Program Studi S1 Manajemen, Universitas Pembangunan Nasional "Veteran” Jakarta \\ E-mail : renyhusniati@gmail.com \\ ${ }^{2}$ Program Studi S1 Akuntansi, Universitas Pembangunan Nasional "Veteran" Jakarta \\ E-mail : yoyog guritno@yahoo.com \\ ProgStudi Manajemen, Universitas Pembangunan Nasional "Veteran” Jakarta \\ E-mail : dewichepe@yahoo.com
}

\begin{abstract}
ABSTRAK
Dodol adalah merupakan usaha yang telah lama dan turun temurun dilakukan oleh warga desa Bojonggede, dalam perkembangannya usaha ini jelas merupakan usaha pokok yang dilakukan warga desa Bojonggede dalam mendapatkan penghasilan, dengan demikian dodol merupakan produk unggulan dari wirausaha yang dilakukan. Namun mereka masih fokus terhadap proses produksi, jualan sebanyak-banyaknya, sedangkan tidak pernah memperhatikan dalam menghitung harga pokok ataupun melakukan pembukuan untuk mengetahui apakah usaha yang dilakukannya mengalami untung atau rugi, bahkan banyak juga yang beranggapan jika selama usaha dikerjakan sendiri, uang tidak akan pergi kemana-mana. Dengan metode ceramah dan praktek langsung dilakukan oleh para pengabdi untuk mengubah pemahaman mereka bahwa pembukuan bukanlah sesuatu yang menyusahkan dan menambah pekerjaan saja tetapi pembukuan dapat mengontrol perkembangan usaha yang sedang berjalan dimana kita akan mengetahui seberapa untung atau rugi yang dialami usaha yang sedang berjalan. Evaluasi dari kegiatan ini adalah menggunakan kuesioner sebelum dan sesudah melaksanakan abdimas, hasil jawaban didapat meningkatnya pemahaman para peserta abdimas terhadap manfaat dari pembukuan (95\%), meningkatnya keyakinan para peserta abdimas bahwa bisnis bisa berkembang dengan melakukan pembukuan (80\%) dan peserta abdimas menghendaki adanya kegiatan abdimas dilakukan kembali dengan tema yang berbeda, sesuai dengan kebutuhan selanjutnya. Peningkatan pengetahuan peserta pengabdian sangat signifikan yaitu $100 \%$ meningkat dalam memahami apa yang dimaksud harga pokok produksi dan apa yang dimaksud pembukuan serta manfaat dari pembukuan itu sendiri.
\end{abstract}

Kata kunci: pelatihan; menghitung harga pokok; pembukuan.

\section{PENDAHULUAN}

Dampak krisis ekonomi global benar-benar mengguncang perekonomian dinegara-negara yang sedang berkembang, termasuk Indonesia, yang belum sepenuhnya bangkit dari krisis moneter yang terjadi ditahun 1997-1998. Kondisi ini sangat memperparah perekonomian. Banyaknya perusahaan-perusahaan besar yang gulung tikar, mengakibatkan sulitnya mencari pekerjaan dimasa sekarang ini. Banyak sekali calon pekerja yang berkeinginan untuk bekerja di instansi pemerintahan atau swasta tetapi lapangan pekerjaan saat ini sangat terbatas, hal ini menyebabkan jumlah pengangguran semakin banyak. Dilihat dari segi ekonomi individual tentu saja masalah pengangguran itu sangat merugikan karena manusia mempunyai kebutuhan yang tidak terbatas. Oleh karena itu sebagai calon tenaga kerja, seharusnya mampu berpikir kreatif dan inovatif yang mampu membaca peluang serta pandai memanfaatkan peluang tersebut sesuai dengan kemampuan yang dimiliki dan tidak terfokus hanya pada satu jenis pekerjaan saja.

Wirausaha merupakan salah satu usaha untuk mengatasi meningkatnya jumlah pengangguran. Selain menguntungkan dari segi ekonomi, sebagaian besar kegiatan wirausaha juga sangat membantu usaha-usaha dalam memenuhi kebutuhan masyarakat banyak, baik secara langsung 
maupun tidak langsung. Menurut (Hendro, 2011) wirausahawan (entrepreneur) adalah orang yang berjiwa berani mengambil resiko untuk membuka usaha dalam berbagai kesempatan. Berjiwa berani mengambil resiko artinya bermental mandiri dan berani memulai usaha, tanpa diliputi rasa takut atau cemas sekalipun dalam kondisi tidak pasti. Menurut (Leonardus Salman, 2009) Kewirausahaan adalah proses kegiatan kreativitas dan inovasi menciptakan perubahan dengan memanfatkan peluang dan sumber sumber yang ada untuk menghasilkan nilai tambah bagi diri sendiri dan orang lain serta mmenangkan persaingan.

Dodol adalah merupakan usaha yang telah lama dan turun temurun dilakukan oleh warga desa Bojonggede, dalam perkembangannya usaha ini jelas merupakan usaha pokok yang dilakukan warga desa Bojonggede dalam mendapatkan penghasilan, dengan demikian dodol merupakan produk unggulan dari wirausaha yang dilakukan masyarakat desa Bojonggede. Dari hasil observasi awal terlihat para pengusaha lebih fokus pada proses produksi, jualan sebanyakbanyaknya, sedangkan mereka tidak memperhatikan dan mencoba menghitung harga pokok dan pembukuannya. banyak juga yang beranggapan jika selama usaha dikerjakan sendiri, uang tidak akan pergi kemana-mana. Kami mencoba memberikan satu pemahaman bahwa penentuan harga pokok produksi bertujuan untuk mengetahui berapa besarnya yang dikorbankan dalam hubungannya dengan pengolahan bahan baku menjadi barang jadi yang siap dijual. Penentuan harga pokok sangat penting dalam suatu usaha, karena merupakan salah satu elemenyang dapat digunakan sebagai pedoman dan sumber informasi bagi pelaku usaha dalam mengambil keputusan. Dan ditekankan pula bahwa pembukuan bukan masalah yang susah, pada dasarnya dapat berfungsi untuk membantu dan mengetahui seberapa besar keuntungan atau kerugian usaha yang dijalani selama ini. Tetapi banyak pemilik atau pengusaha menjalankan aktivitas usaha mereka tanpa pertimbangan akuntansi atau keuangan, mengambil keputusan investasi dan kredit penting tanpa analisis akuntansi dan keuangan. Terkadang pemilik atau manajer UKM gagal memahami tentang status keuangan yang sebenarnya dari bisnis mereka sendiri. Sehingga ada dampak negatif yang signifikan dari praktik akuntansi yang buruk pada pertumbuhan dan keberlanjutan UKM (Udin et dkk, 2017).

Pembukuan adalah suatu proses pencatatan yang dilakukan secara teratur untuk mengumpulkan data dan informasi keuangan yang meliputi harta, kewajiban, modal, penghasilan dan biaya, serta jumlah harga perolehan dan penyerahan barang atau jasa, yang ditutup dengan menyusun laporan keuangan berupa neraca, dan laporan laba rugi untuk periode Tahun Pajak tersebut. Pentingnya pembukuan dalam bisnis ini juga harus didukung dengan pengetahuan si pengusaha. Namun, karena tidak semua orang bisa membuat laporan keuangan yang baik, maka hal tersebut menjadi kendala tersendiri. Terlebih jika pembukuan tersebut masih dilakukan secara manual, berkutat dengan tumpukan kertas, kalkulator, membuat dan mengisi kolom-kolom transaksi, serta harus teliti dalam mencatat data keuangan yang penting. Tentu saja ini akan menghabiskan banyak waktu dan tenaga. Belum lagi adanya resiko human error dalam melakukan kalkulasi.

Terbatasnya pemahaman dan pengetahuan para pengusaha dodol yang ada di lingkungan RW 03 Desa Bojonggede tentang bagaimana menghitung harga pokok dan pembukuannya serta terbatasnya kemampuan dan keterampilan para pengusaha dodol, dalam praktek membuat pembukuan sederhana untuk mempermudah bisnis, merupakan masalah tersendiri. Dengan adanya kegiatan abdimas yang bertujuan memberikan pemahaman dan pengetahuan mengenai bahwa menghitung harga pokok dan membukukannya dapat mempermudah bisnis dan melihat apakah bisnis yang dijalani itu berkembang atau tidak, serta memberikan pengetahuan dan pemahanan kalau pencatatan dilakukan dengan baik, akan lebih mudah untuk bisa mengajukan kredit ke bank. Setelah itu para pelaku usaha mulai tertarik akan pelatihan tentang menghitung 
harga pokok produksi dan melakukan pembukuan tersebut sehingga meminta kami para Dosen memberikan pengetahuannya tentang pembukuan ini

\section{METODE PELAKSANAN}

Berdasarkan identifikasi masalah yang telah dikemukakan tersebut di atas maka Tim merencanakan tiga tahap kerangka pemecahan masalah. Pada tahap pertama untuk pemecahan masalah terbatasnya pemahaman dan pengetahuan para pelaku usaha dodol di RW 03 Desa Bojonggede tentang "Pembukuan mutlak diperlukan bagi pelaku usaha, apapun bidang usahanya", maka Tim merencanakan pendekatan berupa penyuluhan. Tahap kedua untuk meningkatkan kemampuan dan keterampilan pemberian praktek langsung bagaimana cara menghitung harga pokok produksi dan pembukuan sesuai yang dibutuhkan para pelaksana usaha dodol. Tahap ketiga, membangun sikap apresiatif mereka dengan diskusi, tanya jawab dan problem solving berbagai kendala yang sering mereka alami berkaitan juga dengan perencanaan pengembangan usaha

Metode pelaksanaan pada program pengabdian masyarakat ini, yaitu :

1. Memberikan pemahaman yang benar mengenai cara menghitung harga pokok produksi dan cara membukukannya dalam melakukan usaha, sehingga para pelaku usaha warga desa Bojonggede dapat mengerti dan memahami pentingnya pembukuan dan diharapkan mereka benar benar menerapkan dalam usaha yang mereka jalankan.

2. Memberikan pelatihan bagaimana menghitung harga pokok produksi dan cara membukukannya kepada para pelaku usaha di desa Bojonggede, Kecamatan Bojonggede Kabupaten Bogor.

3. Membangun sikap apresiatif mereka dengan diskusi, tanya jawab dan problem solving berbagai kendala yang sering mereka alami berkaitan juga dengan perencanaan pengembangan usaha

4. Evaluasi hasil akhir

Dari kegiatan ini partisipasi mitra diharapkan (1) berperan aktif sebagai peserta dan mengaplikasikan dalam kehidupan usaha sehari-hari dengan melakukan penghitungan harga pokok serta membukukannya sebagai dasar melihat rugi laba usaha yang dilakukannya sehingga dapat mengetahui maju mundurnya usaha. dan (2) berpartisipasi aktif dengan mengikuti praktek secara langsung bagaimana cara menghitung harga pokok dan bagaimana cara membukukannya berdasarkan usaha yang sedang dilakukannya.

Kegiatan pelatihan menghitung harga pokok dan pembukuan ini dilaksanakan hari kamis 9 Agustus 2019. Kegiatan dimulai pukul 08.30 sampai dengan pukul 15.00 . Kegiatan diawali dengan mengumpulkan peserta di rumah salah satu rumah warga (hj. Nonon) di Rw 04 Kampung masjid desa Bojonggede sebagai tempat pelatihan. Target peserta 20 pelaku usaha, yang rata rata sudah melakukan usaha lebih dari 3 tahun. Pada awal kegiatan dilakukan pre test, dimana peserta abdimas mengisi kuesioner yang telah disiapkan oleh tim pengabdi sebanyak 15 (orang) orang berdasarkan khalayak sasaran yang telah ditentukan, dan seluruh kuesioner dikembalikan kepada pengabdi untuk dioalah sehingga dapat menghasilkan informasi. Adapun tujuan dari dilakukan pre test adalah untuk mengetahui sejauh mana pemahaman peserta pelatihan tentang menghitung harga pokok serta membukukannya sebagai dasar melihat rugi laba usaha yang dilakukannya sehingga dapat mengetahui maju mundurnya usaha. Tanggapan dari setiap peserta terhadap pelaksanaan abdimas dapat dilihat dari Tabel 1 . 
Tabel 1 Hasil jawaban peserta pelatihan Menghitung harga pokok serta membukukannya bagi para pengusaha dodol di desa Bojonggede sebelum pelatihan dimulai.

\begin{tabular}{|c|c|c|c|c|c|c|c|}
\hline \multirow{2}{*}{$\begin{array}{l}\text { No } \\
\text {. }\end{array}$} & \multirow{2}{*}{ Pernyataan } & \multicolumn{6}{|c|}{ Kriteria } \\
\hline & & $\mathrm{S}$ & $\%$ & $\mathrm{KS}$ & $\%$ & $\mathrm{TS}$ & $\%$ \\
\hline 1 & $\begin{array}{l}\text { Mengetahui yang dimaksud } \\
\text { menghitung harga pokok }\end{array}$ & 0 & 0 & 2 & 13.33 & 13 & 86.67 \\
\hline 2 & $\begin{array}{l}\text { Mengetahui yang dimaksud } \\
\text { dengan pembukuan }\end{array}$ & 3 & 17.65 & 7 & 46.67 & 5 & 33.33 \\
\hline 3 & Mengetaui manfaat pembukuan & 2 & 13.33 & 4 & 26.67 & 9 & 60.00 \\
\hline 4 & $\begin{array}{l}\text { Pernah membuat pembukuan } \\
\text { sebelumnya }\end{array}$ & 0 & 0 & 2 & 13.33 & 13 & 86.67 \\
\hline 5 & $\begin{array}{l}\text { Pembukuan itu menyusahkan } \\
\text { dan hanya menambah pekerjaan }\end{array}$ & 11 & 73.33 & 2 & 13.33 & 2 & 13.33 \\
\hline 6 & $\begin{array}{l}\text { Merasa yakin bahwa bisnis bisa } \\
\text { berkembang dengan melakukan } \\
\text { pembukuan }\end{array}$ & 1 & 6.67 & 3 & 20.00 & 11 & 73.33 \\
\hline
\end{tabular}

Sumber : Olah Data kuesioner

Dari hasil pre test terlihat bahwa 86,67 \% para peserta tidak mengetahui yang dimaksud menghitung harga pokok, hanya $17,65 \%$ yang mengetahui yang dimaksud dengan pembukuan, pada dasarnya ada $13,33 \%$ mereka mengetahui manfaat dari pembukuan, akan tetap para peserta pengabdian semuanya atau $100 \%$ belum pernah melakukan pembukuan sebelumnya, pemahaman mereka tentang pembukuan hanyalah menambah pekerjaan dan menuysahkan terlihat dari informasi yang ada adalah $73 \%$ setuju bahwa pembukuan menyusahkan dan hanya menambah pekerjaan, serta $73,33 \%$ para peserta tidak yakin bahwa bisnis bisa berkembang dengan melakukan pembukuan.

Dengan berbekal informasi data tersebut, bahwa pengusaha dodol di RW 04 kampung masjid lebih banyak kepada yang tidak mengetahui apa itu pembukuan, mereka tidak pernah melakukan pembukuan sebelumnya serta mereka hanya beranggapan bahwa melakukan pembukuan itu hanya menambah pekerjaan dan menyusahkan, maka kami memastikan harus memberikan pengetahuan kepada pengusaha dodol tersebut bahwa dengan melakukan pembukuan usaha akan lebih terpantau dan dapat melihat apakah usaha ini berkembang atau tidak yang mana dapat dilihat dari rugi labanya.

Acara pelatihan dimulai dengan menyampaikan hal-hal yang berkaitan dengan teori yang menyatakan bahwa pembukuan adalah hal yang wajib dilakukan bagi mereka yang melakukan usaha untuk mengontrol perkembangan usaha, hasil yang terlihat para peserta pengabdian tidak memperlihatkan rasa tertarik terhadap pembukuan karena terlihat mereka diam saja. Kami melakukan simulasi dengan mencontohkan biaya pembuatan dodol dalam wajan yang tersedia di tempat dimana kita berkumpul, terlihat antusias peserta dengan memberikan masukan jumlah bahan baku yang digunakan dalam pembuatan dodol tersebut, dan akan menghasilkan dodol yang siap jual berapa banyak, sehingga akan menghasilkan keuntungan berapa dengan harga 
yang ditetapkan. Setelah terlihat antusias para pengusaha dodol, maka kami melakukan praktek langsung menghitung harga pokok dan sekaligus bagaimana cara membukukannya. Ada tiga kelompok dengan resep masing masing melakukan praktek langsung menghitung harga pokok dan langsung membukukannya. Diskusi berjalan dengan baik, saling bekerjasama memberikan masukan serta bahan dan resep mereka dalam meracik dodol yang enak. Kami pun memberikan pengetahuan bahwa apabila pembukuan dilakukan dengan baik paling tidak dalam 3 tahun bisa dijadikan sebagai pendukung data untuk dapat pinjaman dana pengembangan usaha dari bank. Informasi ini membuka mata para peserta abdimas bahwa pembukuan itu dapat mengontrol usaha mereka dan sekaligus mengetahui apakah usahanya berkembang atau tidak.

Di akhir kegiatan kami melakukan post test dengan menyebarkan kuesioner yang sama dengan yang dibagikan di awal sebelum pelatihan dimulai. Adapun tujuan dilakukan evaluasi adalah untuk mengetahui sampai sejauh mana pemahaman mereka tentang pembukuan. Tanggapan dari setiap peserta terhadap pelaksanaan pengabdian kepada masyarakat tercantum pada Tabel 2 .

Tabel 2 Hasil jawaban peserta pelatihan Menghitung harga pokok serta membukukannya bagi para pengusaha dodol di desa Bojonggede setelah pelatihan selesai.

\begin{tabular}{|c|c|c|c|c|c|c|c|}
\hline \multirow{2}{*}{ No. } & \multirow{2}{*}{ Pernyataan } & \multicolumn{6}{|c|}{ Kriteria } \\
\hline & & $S$ & $\%$ & $\mathrm{KS}$ & $\%$ & TS & $\%$ \\
\hline 1 & $\begin{array}{l}\text { Mengetahui yang dimaksud } \\
\text { menghitung harga pokok }\end{array}$ & 15 & 100.00 & 0 & - & 0 & - \\
\hline 2 & $\begin{array}{l}\text { Mengetahui yang dimaksud } \\
\text { dengan pembukuan }\end{array}$ & 15 & 100.00 & 0 & - & 0 & - \\
\hline 3 & $\begin{array}{l}\text { Mengetaui manfaat } \\
\text { pembukuan }\end{array}$ & 15 & 100.00 & 0 & - & 0 & - \\
\hline 4 & $\begin{array}{l}\text { Akan membuat pembukuan } \\
\text { untuk mengontrol usahanya }\end{array}$ & 13 & 86.67 & 2 & 13.33 & & - \\
\hline 5 & $\begin{array}{l}\text { Pembukuan itu menyusahkan } \\
\text { dan hanya menambah } \\
\text { pekerjaan }\end{array}$ & 0 & - & 2 & 13.33 & 13 & 86.67 \\
\hline 6 & $\begin{array}{l}\text { Merasa yakin bahwa bisnis } \\
\text { bisa berkembang dengan } \\
\text { melakukan pembukuan }\end{array}$ & 13 & 86.67 & 2 & 13.33 & 0 & - \\
\hline
\end{tabular}

Sumber : Data hasil Olah kuesioner

Dari hasil post test terlihat bahwa semua peserta atau $100 \%$ mengetahui mengetahui yang dimaksud dengan menghitung harga pokok, dan $100 \%$ juga mereka mengetahui yang dimaksud dengan pembukuan, artinya semua peserta atau $100 \%$ mengetahui manfaat dari pembukuan. Walaupun tidak semua kedepannya akan membuat pembukuan tetapi 86,7 \% tertarik akan mencoba memulai usahanya ke depan akan membuat pembukuan. 86,67 \% sudah berpendapat bahwa pembukuan itu memang menambah pekerjaan tetapi ternyata cukup bermanfaat, serta mereka yakin bahwa bisnis mereka bisa berkembang dengan melakukan pembukuan, terlihat dari jawaban mereka sebesar $86,67 \%$. 


\section{HASIL DAN PEMBAHASAN}

Berdasarkan hasil kegiatan pengabdian kepada masyarakat, bahwa kegiatan pengabdian ini mendapat respon yang positif dari para peserta, yaitu para pengusaha dodol yang ada di Rw 04 kampung masjid desa Bojonggede Kecamatan bojonggede Kabupaten Bogor. Peningkatan pengetahuan peserta pengabdian sangat signifikan yaitu $100 \%$ meningkat dalam memahami apa yang dimaksud harga pokok produksi dan apa yang dimaksud pembukuan serta manfaat dari pembukuan itu sendiri. Masih ada 13,33 \% yang menyatakan belum melakukan pembukuan, ternyata mereka terkendala dengan orang yang akan melakukan pembukuannya karena pengusaha dodol ini sudah berumur diatas 60 tahun dan hanya mempekerjakan orang pengaduk dodol, jadi mereka tidak yakin bisa melakukan pembukuan. Bagi mereka masih berpendapat bahwa pembukuan itu menambah pekerjaan yang tidak bisa mereka lakukan, dan mereka berpendapat usahanya masih bisa jalan tanpa melakukan pembukuan.

Diakhir pertemuan, para peserta merasa banyak hal yang perlu mereka tanya dan diskusikan, tentang perkembangan usaha mereka dari pengemasan, pemasaran, pembuatan proposal dana ke bank dan pengetahuan lainnya sehingga para peserta abdimas meminta untuk para pengabdi bisa datang secara periodik untuk mendampingi para pelaku usaha dodol kearah yang lebih berkembang.

\section{KESIMPULAN DAN SARAN}

Pelatihan menghitung harga pokok dan membukukannya yang dilakukan pada pelaku usaha dodol di RW 04 kampung masjid desa Bojonggede, Kecamatan Bojonggede, Kabupaten Bogor, berhasil memberikan pemahaman kepada peserta abdimas bahwa pembukuan bermanfaat untuk melihat perkembangan usaha. Peningkatan yang sangat signifikan atas pengetahuan para peserta abdimas memperlihatkan bahwa kami cukup berhasil dapat memotivasi para pelaku usaha untuk keluar dari zona amannya sehingga dapat bersaing dengan pelaku usaha lainnya. Mengubah persepsi orang lain bukanlah hal yang mudah, tetapi dengan para peserta pengabdian meminta kami untuk datang secara periodik untuk mendampingi mereka dengan pengetahuan dalam wira usaha memperlihatkan bahwa kami berhasil mengubah pemikiran mereka ke arah yang lebih berkembang.

Disarankan ada komitmen diantara para pengabdi dan peserta pengabdian untuk mencoba menerapkan pembukuan dalam mengelola usahanya, serta ada kesadaran dari para pengabdi untuk memilih tempat yang sama dalam kegiatan pengabdian lainnya supaya dapat berkesinambungan memberikan bahkan mendampingi ke arah pengembangan usaha yang lebih baik. Pada dasarnya peserta abdimas menghendaki adanya kegiatan abdimas dilakukan kembali dengan tema yang berbeda, sesuai dengan kebutuhan selanjutnya

\section{REFERENSI}

Hendro, 2011, Dasar-dasar Kewirausahaan, Panduan Bagi Mahasiswa Untuk mengenal, Memahami, dan Memasuki Dunia Bisnis. Airlangga

Leonardus Salman, 2009, Kewirausahaan, Teori, praktek dan Kasus-kasus, Salemba empat

Rahmady Radiani, 2006, Alternatif Menjadi Kaya, Badan Penerbit Mahardika

Udin R, dkk. 2017, Accounting Practices of Small and Medium Enterprises in Rangpur,

Bangladesh . Journal of Business \& Financial Affairs DOI: 10.4172/2167-

0234.1000299 